\title{
Effect of Vacuum Impregnation Temperature on the Mechanical Properties and Osmotic Dehydration Parameters of Apples
}

\author{
Sabrina Silva Paes, Gustavo Beulke Stringari and João Borges Laurindo* \\ Laboratório PROFI; Departamento de Engenharia Química e Engenharia de Alimentos; Universidade Federal de \\ Santa Catarina; C.P.: 476; joao@enq.ufsc.br; 88040-900; Florianópolis - SC - Brasil
}

\begin{abstract}
The effect of sucrose solution temperature on the mechanical properties, water loss (WL), solids gain (SG) and weight reduction (WR) of apples (Fuji var.) treated by vacuum impregnation was studied. Temperatures were varied from 10 to $50^{\circ} \mathrm{C}$, using a sucrose solution of $50^{\circ}$ Brix. The mechanical properties were studied throughout a stress relaxation test. The results showed that the SG varied between 10.57 and $14.29 \%$ and the WL varied between 10.55 and $14.48 \%$. The treated fruit soluble solids increased with the temperature probably due to the lower viscosity of the solution. The maximum stress was highest at $10^{\circ} \mathrm{C}$, decreasing at higher temperatures, probably due the softening of the structure.
\end{abstract}

Key words: Vacuum, impregnation, temperature, solids, water, texture

\section{INTRODUCTION}

Investigations into alternative or new techniques to process fruit is necessary to obtain new and high quality products (Canteri-Schemin et al, 2005). Osmotic dehydration and vacuum impregnation are two useful techniques for these purposes. Controlled vacuum impregnation consists of filling porous fractions of a porous product with an external solution of desired composition. This process is carried out by applying vacuum pressure $\left(\mathrm{P}_{1}\right)$ to the tank which contains the product immersed in a solution for a time $\left(\mathrm{t}_{1}\right)$ sufficient for it to be de-aired, and subsequently restoring the pressure to atmospheric pressure $\left(\mathrm{P}_{2}\right)$ while the product remains immersed for time $\left(\mathrm{t}_{2}\right)$ (MartínezMonzo et al, 1998).

It has been reported that the use of vacuum in osmotic treatments (VI) allows an increase in the rate of water loss (WL), solids gain (SG) and a controlled impregnation of desired solutes in foods (Moreno et. al, 2004; Shi and Fito, 1994; Fito, 1994; Fito et al., 1996; Martínez-Monzo et al., 1998; Tapia et al., 1998; Mújica-Paz et al., 2003a, b). The first study with a theoretical mathematical model to explain what occurs in each step of the VI process was presented by Fito (1994). The author defined the Hydrodynamic Mechanism (HDM), where the volumetric fraction of the sample impregnated $(X)$ was modeled as

\footnotetext{
* Author for correspondence
} 
afunction of a food effective porosity $\left(\mathcal{E}_{\mathrm{e}}\right)$ and of an apparent compression rate $(r)$. This relationship is shown in Eq. (1).

$$
X=\varepsilon_{e}\left(1-\frac{1}{r}\right)
$$

Fito et al. (1996) proposed a physical model that takes into account the influence of the pressure gradient created by the vacuum, as well as atmospheric restoration steps on the solution flow and food matrix deformations. If foods are considered as viscoelastic materials, the above authors proposed the following model, represented by Equation (2).

$$
X-\gamma=\left(\varepsilon_{e}+\gamma\right)\left(1-\frac{1}{r_{2}}\right)-\gamma_{1}
$$

Where $X$ is the volumetric fraction of the sample occupied by a liquid as a result of hydrodynamic mechanisms, $\gamma$ is the relative sample deformation at the end of the atmospheric pressure step, $\varepsilon_{e}$ is the effective porosity, $r_{2}$ is the apparent compression rate at the atmospheric pressure step and $\gamma_{1}$ is the relative sample deformation at the end of the vacuum step. The relative sample deformation $(\gamma)$ is defined as the volumetric fraction of the sample that was deformed during the vacuum impregnation treatment.

Few studies have focused on the effect of the VI treatment conditions on the deformation of samples (Martínez-Monzó et al., 1998, Cháfer et al., 2003). The main changes induced by osmotic treatment which affect the mechanical behaviour of plant tissues are loss of cell turgor, cell debonding, alterations in cell wall resistance, density of cell packaging, sample size and shape, temperature (Vincent, 1994, Pitt 1992), changes in water and solute concentration profiles (Salvatori et al., 1998), and changes in air and liquid volumetric fraction in the sample (Fito, 1994). The viscoelastic properties of solid foods have frequently been demonstrated by relaxation curves (Peleg, 1980). In a stress relaxation test the sample is submitted to a predetermined strain and the stress required to maintaining the deformation is observed as a function of time. Viscoelastic materials relax gradually with the end point depending on the molecular structure of the material being tested. In viscoelastic solids the stress decays to an equilibrium stress $\sigma_{e}$ (where $\sigma>0$ ) (Steffe, 1996).

Peleg (1979) tested a model where the relaxation curves were normalized and the decaying parameter was calculated by Equation (3).

$Y(t)=\frac{F(0)-F(t)}{F(0)}$

Where $Y(t))$ is the decaying parameter, $F(0)$ the initial force and $F(t)$ is the force recorded after $t$ minutes of relaxation. Since in stress relaxation the strain is fixed, the parameter $Y(t)$ represents the stress or apparent modulus decay in exactly the same way (Peleg, 1979, Peleg 1980). The shape of the curves for $Y(t)$ vs. $t$ suggests a simplified calculation in the form of equation 4 , resulting in a straight line, where $a$ and $b$ are constants. The parameter $a$ represents the level to which the stresses decay during relaxation. The constant $b$ represents the rate at which the stress relaxes $(1 / b$ is the time necessary to reach a level of $a / 2$ ). If $a=0$, the stress does not relax at all (this is typical behaviour of an ideal elastic solid) and if $a=1$ the stress level eventually reaches zero (this is typical behaviour of a liquid). It also represents the portion of the stress that remains unrelaxed at equilibrium (Peleg, 1979).

$$
\frac{t}{Y(t)}=\frac{1}{a \cdot b}+\frac{t}{a}
$$

Another way to quantify changes in mechanical properties by means of a stress relaxation test is to determine the relaxation time. This is defined as the time required for the stress, at constant strain, to decrease to $1 / e$ of its original value, where $e$ is the base of the natural logarithm. Since $1 / e=0.3678$, the relaxation time is the time required for the force to decay to $36.8 \%$ of its original value (Peleg, 1980).

The aim of this work was to investigate how the temperature of a VI process affected the following properties of samples submitted to this process; water loss (WL), solids gain (SG) and mechanical properties of apples. The behaviour of fresh apple samples and 'heated' apple samples that were submitted to a VI process with different temperatures was compared by using a stress relaxation test. 


\section{MATERIAL AND METHODS}

\section{Sample Preparation}

Fresh apples (Fuji var.) were purchased from a local market and kept refrigerated until use. The samples were selected on the basis of the similar degree of ripening by Brix and fruit firmness. Before use, the samples were removed from refrigeration and left to equilibrate in an oven at 20 ${ }^{\circ} \mathrm{C}$ and $75 \%$ relative humidity. Cylindrical samples $(1.37 \pm 0.08 \mathrm{~cm}$ height and $1.51 \pm 0.01$ $\mathrm{cm}$ diameter) were taken from the apple along a parallel axis. Osmotic solutions were prepared with commercial sucrose.

The average height and diameter of seven samples were calculated from the measurements using a digital external Mitutoyo micrometer, model Digimatic-Japan, with a precision of $0.001 \mathrm{~mm}$. These values were used to determine the average volume of the sample before and at the end of the VI process. The volume reduction was calculated using the following equation.

$V R=\frac{V_{0}-V}{V_{0}} \cdot 100$

where $V_{0}$ is the initial volume of the sample $\left(\mathrm{cm}^{3}\right)$ and $V$ is the volume of the sample at the end of the VI process $\left(\mathrm{cm}^{3}\right)$.

\section{Physicochemical Analysis}

Moisture and soluble solids content were determined in both fresh and osmotically dehydrated samples. A refractometer was used to determine the soluble solids concentration of sucrose solutions. Moisture content was quantified by drying the samples at $105{ }^{\circ} \mathrm{C}$ in an oven until constant weight was achieved. All moisture determinations were made in triplicate and the average was used.

Fruit apparent density and real density were determined using a pycnometer-based method (Salvatori et al., 1998). The apparent density was determined by measuring the volume of the sample by displacement, using a pycnometer with an isotonic solution as a reference liquid. The real density was measured on the previously pulped, homogenized and de-aired (pressure of $260 \mathrm{mbar}$ for $2 \mathrm{~h}$ ) sample in order to withdraw the occluded air. All determinations were made in triplicate. Sample porosities were calculated from apparent and real densities according to Eq. (6):

$$
\varepsilon=1-\frac{\rho_{b}}{\rho_{s}}
$$

where $\rho_{s}$ is the real density and $\rho_{b}$ is the apparent density.

\section{VI treatment}

The VI treatments were carried out in a jacketed chamber at constant temperature. In order to calculate WL and SG, the samples were weighed individually and submerged in the $50{ }^{\circ}$ Brix sucrose solution for $25 \mathrm{~min}$ at a pressure of 40 mbar followed by a relaxation period of $15 \mathrm{~min}$. The temperatures of the VI process that were being investigated were $10,20,30,40$ or $50^{\circ} \mathrm{C}$.

A 1:50 fruit:syrup mass ratio was used which was high enough to avoid significant changes in the sugar concentration. After impregnation, the samples were drained and the solution that adhered to the surface of the samples was removed with a tissue paper that was placed for $5 \mathrm{~s}$ on each side; the fruit samples were then weighed and the moisture and dry solids content were determined. In each treatment, the VI parameters were calculated using Eq. (7) and Eq. (8):

$$
\begin{aligned}
& W L=\frac{w_{w 0}-w_{w}}{w_{0}} \cdot 100 \\
& S G=\frac{w_{s}-w_{s 0}}{w_{0}} \cdot 100
\end{aligned}
$$

where $\mathrm{w}_{\mathrm{w} 0}$ is the initial weight of water in the sample $(\mathrm{kg}), \mathrm{W}_{\mathrm{w}}$ is the weight of water in the sample at the end of the treatment $(\mathrm{kg}), \mathrm{w}_{\mathrm{o}}$ is the initial weight of the sample $(\mathrm{kg}), \mathrm{w}_{\mathrm{s}}$ is the weight of dry solids at the end of the treatment $(\mathrm{kg}), \mathrm{w}_{\mathrm{s} 0}$ is the initial weight of dry solids in the sample $(\mathrm{kg})$, and $\mathrm{w}$ is the weight of the sample at the end of the treatment $(\mathrm{kg})$. Analysis of variance (ANOVA-one way) was performed on the experimental results (Gagula and Singh, 1984) to determine the effect of the treatment on the osmotic dehydration parameters. 
Measurement of mechanical properties - Stress Relaxation test

Mechanical properties of fresh and vacuum osmotic dehydrated samples were investigated by a stress relaxation test using a universal testing machine (TA.XT2 Texture Analyser, Stable Micro Systems, Helsemere, England). Test conditions were $200 \mathrm{~mm} / \mathrm{min}$ with deformation of 0.54 $\mathrm{mm} / \mathrm{mm}$ constant strain. Seven samples were tested and the average results are presented. A schematic representation of these methods is presented in the Fig. 1.

The relaxation curves were normalized and fitted to the Peleg model (Eq. (4)) and the constants $a$ and $b$ were estimated by fitting the model to experimental data. The relaxation time and the maximum stress were also determined.

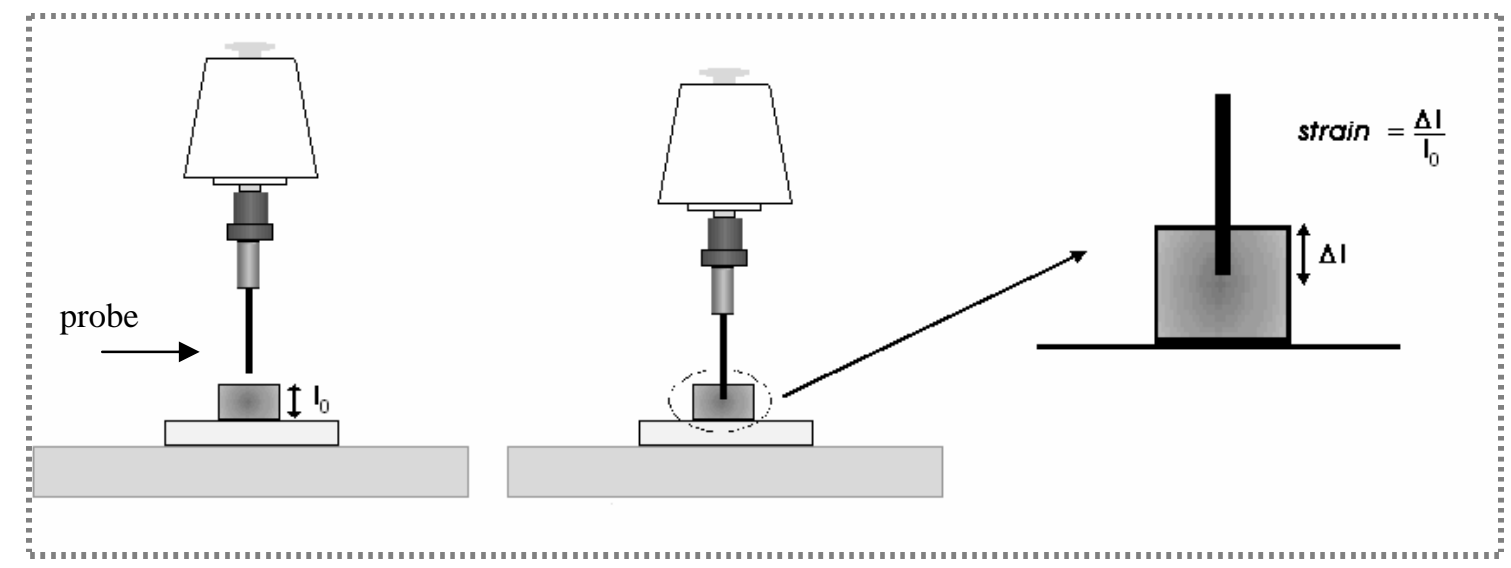

Figure 1 - Schematic representation of the relaxation test. $1_{0}$ : initial height and $\Delta \mathrm{l}$ : length of deformation.

\section{RESULTS AND DISCUSSION}

Physicochemical properties of fresh apple samples used in this work are presented in Table 1. The reported values are the average of eight repeats. Real porosity $(\varepsilon)$ constitutes a measure of the empty spaces in the fruit tissue, and represents the maximum space that could be impregnated with an isotonic solution. The $\varepsilon$ value obtained (0.205) was close to the range $0.216-0.238$, reported by Salvatori et. al (1998) of for various apple varieties.

Table 1 - Physicochemical properties of 'Fuji' Apple.

\begin{tabular}{lc}
\hline Property & \\
\hline Moisture content $(\mathrm{kg}$ water/ $/ \mathrm{kg}$ sample) & $0.870 \pm 0.008$ \\
Total soluble solids $\left({ }^{\mathrm{B} B r i x}\right)$ & $13.2 \pm 0.8$ \\
Apparent density $\left(\mathrm{kg} / \mathrm{m}^{3}\right)$ & 0.852 \\
Real density $\left(\mathrm{kg} / \mathrm{m}^{3}\right)$ & 1.072 \\
Porosity & 0.205
\end{tabular}

The effect of the process temperature on the soluble solid content in the samples at the end of the VI treatment is shown in Fig. 2. As seen, the final soluble solids content increased as the solution temperature increased. For $10^{\circ} \mathrm{C}$ the final soluble solids content was $23.0^{\circ} \mathrm{Brix}$ whereas the maximum soluble solid content was found in the process performed at $50{ }^{\circ} \mathrm{C}\left(32.5^{\circ} \mathrm{Brix}\right)$. This could be explained by the effect of blanching, which changed the selectivity of the cell membrane, increasing the diffusion of solutes from the solution into the product. However, this increase might be a combined effect of both the impregnation and dehydration at these 
temperatures and the concomitant decrease of viscosity as temperature increases. These effects might be elucidated by the determination of the parameters water loss (WL) and solids gain (SG), since these parameters allowed the analysis of the impregnation and dehydration effects separately. The WL and SG values for the VI processes at different temperatures are presented in Fig. 3.

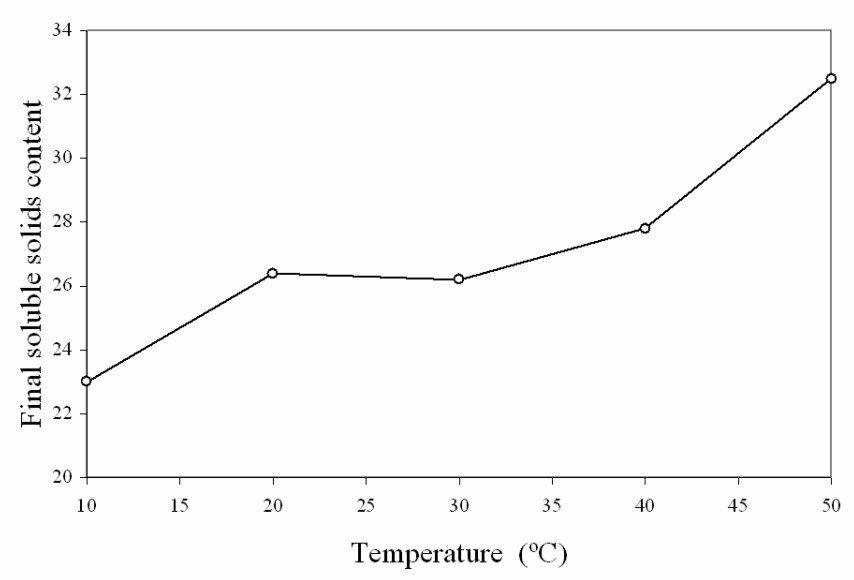

Figure 2 - Effect of the temperature on the final soluble solids content of apples at the end of the VI treatment with varying temperature. Treatment was with sucrose solution $\left(50^{\circ} \mathrm{Brix}\right)$ for $25 \mathrm{~min}$ at a pressure of 40 mbar followed by a relaxation period of $15 \mathrm{~min}$.

Water loss and solid gain are mainly controlled by the raw material characteristics (Torreggiani, 1993). At high $\left(>40{ }^{\circ} \mathrm{C}\right)$ or low $\left(<10{ }^{\circ} \mathrm{C}\right)$ temperatures changes in the fruit structure affect its dehydration and impregnation properties.

The rate of mass exchanges increased with temperature but above $45^{\circ} \mathrm{C}$ enzymatic browning and flavour deterioration start to take place at detectable rates. Heat processing in the temperature range of $45-55{ }^{\circ} \mathrm{C}$ can affect the texture and cause softening of the plant tissues. This thermal softening could be associated mainly with changes in the structure, but also with the damage of membranes.

Analysis of variance showed that the influence of the process temperature for both the parameters $\mathrm{WL}$ and SG was significant $(\mathrm{P}<0.05)$. The water loss increased with a process temperature of between $20-40{ }^{\circ} \mathrm{C}$, as expected. For temperatures above or below this range, this trend was not observed. For the process temperature of $50{ }^{\circ} \mathrm{C}$, the lower WL value was probably a result of a significant softening of the fruit tissue.

The solid gain was not greatly affected by the process temperature. It was expected that at higher temperatures, the lower viscosities would favour the impregnation of the solution into the fruit pores. This trend was observed for temperatures up to $30^{\circ} \mathrm{C}$. For higher temperatures $\left(>40^{\circ} \mathrm{C}\right)$, the solid gain was lower, probably due to the modification of the fruit tissue (softening), which could have resulted in a higher resistance to solution impregnation due to the shrinkage and therefore, decrease of the pore spaces. On the other hand, the modification of the cell membrane might cause it to become less selective, and this might facilitate the native liquid outflow from the cell. This increase of water loss without a great modification of sugar gain when process temperature is increased has been observed by many authors (Ponting, 1966; Hawkes and Flink, 1978; Islam and Flink, 1982). This phenomenon is essentially due to the diffusional differences between water and sugar, related to their different molar masses (Torregiani, 1993).

The volume reduction of the apple samples at the end of the VI process with different temperatures is presented in Fig. 4. 


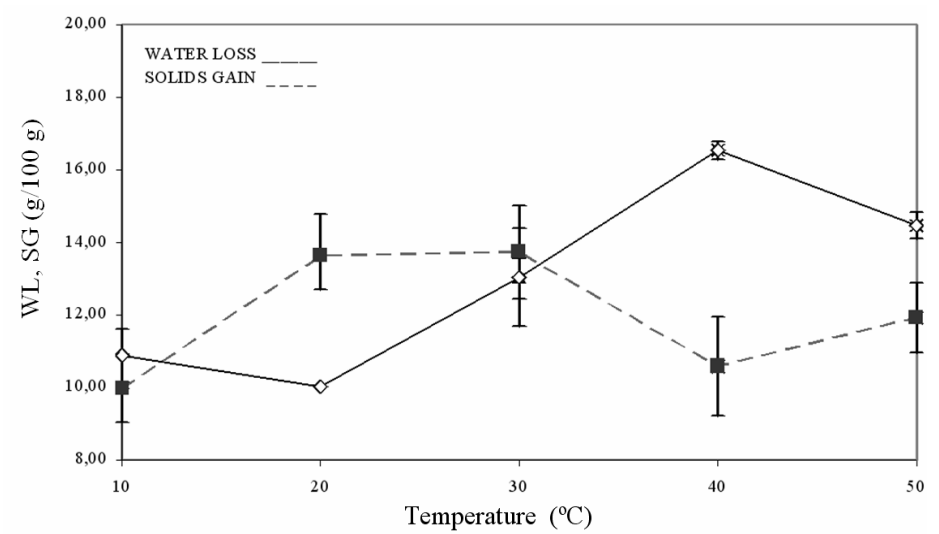

Figure 3 - Water Loss and Solid Gain for apples submitted to a VI process at different temperatures. Treatment was with sucrose solution $\left(50{ }^{\circ} \mathrm{Brix}\right)$ for $25 \mathrm{~min}$ at a pressure of $40 \mathrm{mbar}$ followed by a relaxation period of $15 \mathrm{~min}$.

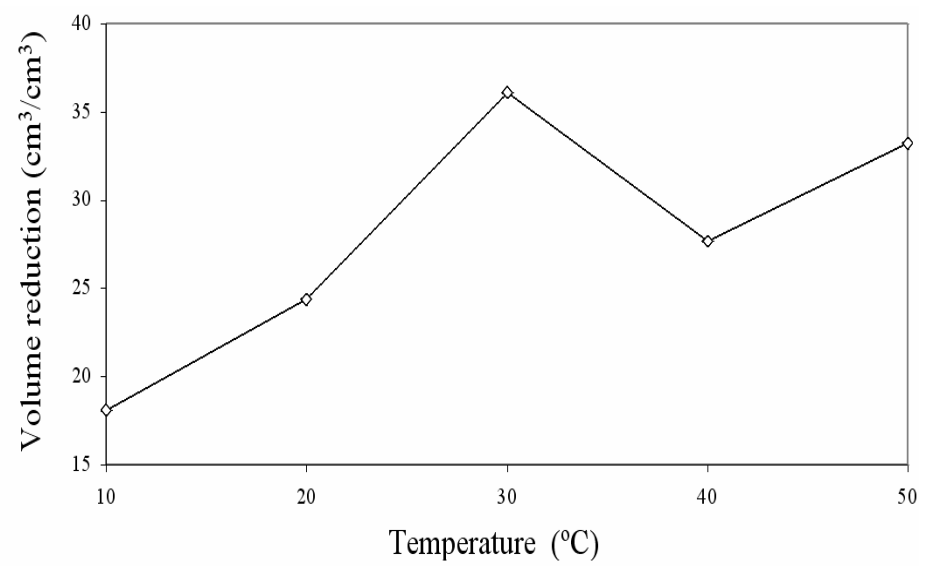

Figure 4 - Volume reduction of apples submitted to a VI process at different temperatures. Treatment was with sucrose solution $\left(50^{\circ} \mathrm{Brix}\right)$ for $25 \mathrm{~min}$ at a pressure of $40 \mathrm{mbar}$ followed by a relaxation period of $15 \mathrm{~min}$.

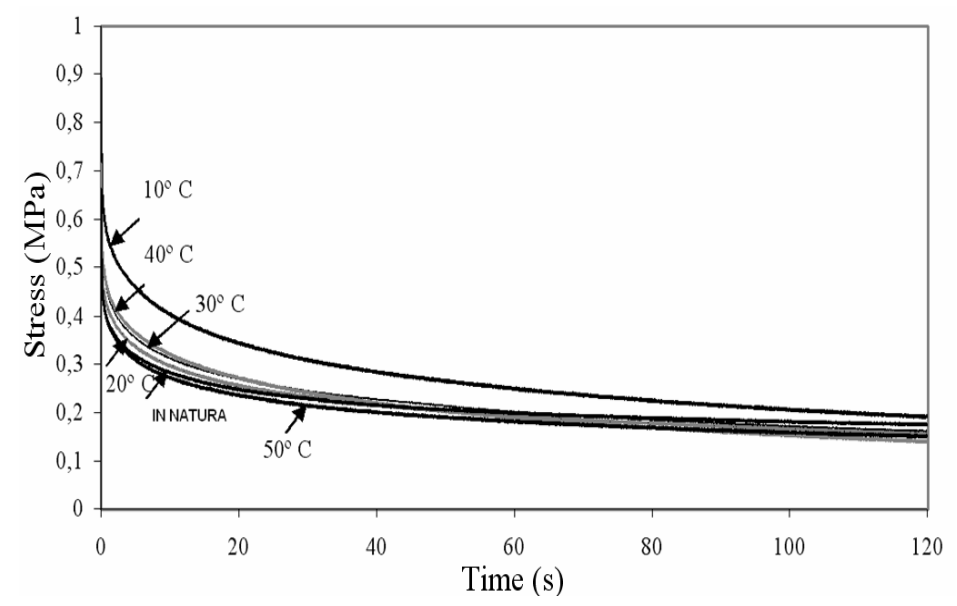

Figure 5 - Relaxation curves for apple samples submitted to a VI process with varying temperature. Treatment was with sucrose solution ( $\left.50^{\circ} \mathrm{Brix}\right)$ for $25 \mathrm{~min}$ at a pressure of $40 \mathrm{mbar}$ followed by a relaxation period of $15 \mathrm{~min}$. 
The average value for volume reduction was close to $30 \%$ over the temperature range 20 to $50{ }^{\circ} \mathrm{C}$, which covered the usual process temperature. The stress relaxation curves for fresh samples and those treated with different VI process temperatures are shown in Fig. 5. It was observed that the VI process temperature of $10^{\circ} \mathrm{C}$ promoted a significant change in the sample relaxation curve. For the other processing temperatures, the relaxation curves were close to the fresh sample one.

The influence of the processing temperature on the Peleg model parameters is shown in Table 2. Analysis of variance showed that the process temperature had a significant effect in the parameter $a$ (level of relaxation) $(\mathrm{P}<0.05)$ but not in the parameter $b(\mathrm{P}>0.05)$. The relaxation time was not affected by the processing temperature $(\mathrm{P}>0.05)$ and presented high standard deviation values. For this reason, it was not an appropriate parameter to analyse the viscoelastic behaviour changes of the samples.

Maximum stress was higher for the temperature of $10{ }^{\circ} \mathrm{C}$, because at this temperature the sample was more rigid than the fresh sample (which was evaluated at $20^{\circ} \mathrm{C}$ ). This could be explained also by the higher moisture content of the samples at the end of the VI process due to less dehydration at $10{ }^{\circ} \mathrm{C}$ (Fig. 3). As expected, at $50{ }^{\circ} \mathrm{C}$ the maximum stress was the lowest, due to the softening of the fruit tissue. For the processing temperatures of $20-40{ }^{\circ} \mathrm{C}$ a clear trend in the maximum stress was not observed.

Table 2 - Effect of the VI processing temperature on Peleg parameters ( $a$ and $b$ ), relaxation time and maximum stress. Treatment was with sucrose solution $\left(50^{\circ} \mathrm{Brix}\right)$ for $25 \mathrm{~min}$ at a pressure of $40 \mathrm{mbar}$ followed by a relaxation period of $15 \mathrm{~min}$.

\begin{tabular}{ccccccccc}
\hline $\begin{array}{c}\text { Temperature } \\
\left({ }^{\mathbf{O}} \mathbf{C}\right)\end{array}$ & \multicolumn{2}{c}{} & \multicolumn{2}{c}{$\begin{array}{c}\boldsymbol{b} \\
(\mathbf{1} / \mathbf{s})\end{array}$} & $\begin{array}{c}\text { Relaxation Time } \\
(\mathbf{s})\end{array}$ & \multicolumn{2}{c}{$\begin{array}{c}\text { Maximum Stress } \\
(\mathbf{M P a})\end{array}$} \\
\hline $\begin{array}{c}\text { Fresh apple } \\
\text { samples }\end{array}$ & 0.750 & \pm 0.021 & 0.264 & \pm 0.030 & 21.135 & \pm 4.559 & 0.663 & \pm 0.093 \\
\hline 10 & 0.807 & \pm 0.032 & 0.157 & \pm 0.017 & 24.007 & \pm 6.424 & 0.894 & \pm 0.085 \\
20 & 0.776 & \pm 0.017 & 0.180 & \pm 0.042 & 25.795 & \pm 6.584 & 0.635 & \pm 0.076 \\
30 & 0.789 & \pm 0.039 & 0.163 & \pm 0.012 & 26.558 & \pm 8.713 & 0.691 & \pm 0.066 \\
40 & 0.838 & \pm 0.035 & 0.161 & \pm 0.046 & 20.474 & \pm 5.491 & 0.734 & \pm 0.131 \\
50 & 0.778 & \pm 0.036 & 0.193 & \pm 0.018 & 24.079 & \pm 6.902 & 0.575 & \pm 0.085 \\
\hline p-value & 0.009 & \multicolumn{2}{c}{0.272} & \multicolumn{2}{c}{0.535} & \multicolumn{2}{c}{$6.541 .10^{-5}$} \\
\hline
\end{tabular}

\section{CONCLUSIONS}

The temperature used in the vacuum impregnation treatment had a significant effect on the dehydration (WL) and impregnation (SG) of apple samples. The effect of temperature on the water loss was much higher than for solids gain. Higher temperatures $\left(>40^{\circ} \mathrm{C}\right)$ caused softening of the samples resulting in lower dehydration. The effect of the temperature on the viscoelastic behaviour of the samples could be analyzed by a relaxation test. The Peleg model fitted well with the data from the stress relaxation curves and could be useful for the analysis of the deformation of samples after a VI process. The $b$ parameter (relaxation rate) did not change significantly with processing temperature. The effect of temperature on the mechanical behaviour of the samples was more clearly observed at the lowest temperature $\left(10^{\circ} \mathrm{C}\right)$, where the samples were more rigid at the end of the VI process than for the higher temperature where the samples became softer after the VI process. The relaxation times showed high standard deviation values, hence relaxation time was not seen as an appropriate parameter to analyse the viscoelastic behaviour changes of the samples.

\section{ACKNOWLEDGMENTS}

The authors wish to thank CNPq and CAPES for granting scholarships to G.B.S. and to S.S.P., respectively. 


\section{RESUMO}

A impregnação a vácuo (VI) de alimentos é realizada pela aplicação de vácuo em um tanque contendo o produto imerso em uma solução, seguida da recuperação da pressão atmosférica. Neste trabalho, estudou-se o efeito da temperatura da solução de sacarose nas propriedades mecânicas das amostras e na perda de água (WL), ganho de sólidos (SG) e redução de peso (WR). A faixa de temperaturas estudada foi de 10 a $50{ }^{\circ} \mathrm{C}$, usando uma solução de sacarose com $50{ }^{\circ}$ Brix. As propriedades mecânicas das amostras foram estudadas através de ensaios mecânicos de deformação-relaxação. O SG variou entre 10.57 e $14.29 \%$, enquanto WL variou entre 10.55 e 14.48 $\%$. O teor de sólidos das frutas tratadas aumentou com a temperatura, provavelmente devido à diminuição da viscosidade da solução. A tensão máxima foi maior a $10{ }^{\circ} \mathrm{C}$, diminuindo com a temperatura, devido ao amolecimento da estrutura.

\section{REFERENCES}

Canteri-Schemin, M. H., Fertonani, H. C. R., Waszczynskyj, N., Gilvan Wosiacki (2005) Extraction of pectin from apple pomace. Braz. Arch. Biol. Technol., 48(2), 259.

Cháfer, M. González-Martínez, C., Fernández , B., Pérez, L. and Chiralt, A. (2003). Effect of blanching and vacuum pulse application on osmotic dehydration of pear. Food Science and Technology International, $9(5), 321$

Fito, P. (1994). Modelling of vacuum osmotic dehydration of food. Journal of Food Engineering, 22, 313

Fito, P., Andrés, A., Chiralt, A. and Pardo P. (1996). Coupling of hydrodynamic mechanism and deformation-relaxation phenomena during vacuum treatments in solid porous food-liquid systems. Journal of Food Engineering, 27(3), 229.

Gagula M.C. and Singh J. (1984). Statistical methods in food and consumers research. Orlando, FL: Academic Press.

Hawkes, J and Flink, J. M. (1978). Osmotic concentration of fruit slices prior to freeze dehydration. International Journal of Food Processing and Preservation, 2, 265.

Islam, M. N.; Flink, J. N. (1982). Dehydration of potato .2. Osmotic concentration and its effect on air drying behaviour. Journal of Food Technology, 17, 387.

Martínez-Monzó, J., Martínez-Navarrete, N., Chiralt, A. and Fito, P. (1998). Mechanical and structural changes in apple (var. Granny Smith) due the vacuum impregnation with cryoprotectantṣ. Journal of Food Science, 63(3), 499.

Moreno, J., Bugueño, G.,Velasco, V., Petzold, G. and Tabilo-Munizaga, G. (2004). Osmotic dehydration and vacuum impregnation on physicochemical properties of Chilean Papaya (Carica candamarcensis). Journal of Food Science, 69(3), 102.

Mújica-Paz, H., Valdez-Fragoso, A., López-Malo, A., Palou, E. and Welti-Chanes J. (2003a). Impregnation and osmotic dehydration of some fruits: effect of the vacuum pressure and syrup concentration. Journal of Food Engineering, 57(4), 305.

Mújica-Paz, H., Valdez-Fragoso, A., López-Malo, A., Palou, E. and Welti-Chanes J. (2003b). Impregnation properties of some fruits at vacuum pressure. Journal of Food Engineering, 56(4), 307.

Peleg, M. (1979). Characterization of the stress relaxation curves of solid foods. Journal of Food Science, 44, 277.

Peleg, M. (1980). Linearization of relaxation and creep curves of solid biological materials, Journal of Rheology, 24, 451.

Pitt, R. E. (1992). Viscoelastic properties of fruits and vegetables. In: Viscoelastic Properties of Foods. London, New York: Elsevier Applied Science Publishers.

Ponting, J. D., Walters, G. G., Forrey, R. R., Jackson, R. and Stanley, W. L. (1966). Osmotic dehydration of fruits. Food Technology, 20, 125.

Salvatori, D., Andrés, A., Chiralt, A. and Fito, P. (1998). The response of some properties of fruits to vacuum impregnation. Journal of Food Process Engineering, 21, 59.

Shi, X. Q. and Fito, P. (1994). Mass transfer in vacuum osmotic dehydration of fruits: a mathematical model approach. Lebensmittel- Wissenschaft und Technologie , 27(1), 67.

Steffee, J. F. Rheological. (1996). Methods in Food Process Engineering, Freeman Press, East Lansing, MI, USA.

Tapia, M. S., López-Malo A., Consuegra R., Corte P. and Welti-Chanes. J. (1998). Minimally processed papaya by vacuum osmotic dehydration (VI) techniques. Food Science and Technology International, 5 (1), 41.

Torreggiani, D. (1993), Osmotic dehydration in fruits and vegetable processing. Food Research International, 26, 59.

Vincent, J. F. V. (1994) Texture of plants. In: Vegetables and vegetable products. H.F. Linskens; J.F. Jackson (Eds.), Springer-Verlag, BerlinHeidelberg.

Received: September 26, 2005; Revised: July 13, 2006; Accepted: March 14, 2008. 